\title{
44. CENOZOIC PALEOCEANOGRAPHY IN THE SOUTHWEST PACIFIC OCEAN, ANTARCTIC GLACIATION, AND THE DEVELOPMENT OF THE CIRCUM-ANTARCTIC CURRENT
}

\author{
James P. Kennett, ${ }^{1}$ Robert E. Houtz, ${ }^{2}$ Peter B. Andrews, ${ }^{3}$ Anthony R. Edwards, ${ }^{4}$ \\ Victor A. Gostin, ${ }^{5}$ Marta Hajós, ${ }^{6}$ Monty Hampton, ${ }^{7}$ D. Graham Jenkins, ${ }^{8}$ Stanley V. Margolis, \\ A. Thomas Ovenshine, ${ }^{10}$ and Katharina Perch-Nielsen ${ }^{11}$
}

\begin{abstract}
Cenozoic deep-sea sedimentation in the southwest Pacific area was controlled by large changes in the patterns of bottom-water circulation and erosion. The circulation patterns were largely controlled by the development of the Circum-Antarctic Current south of Australia. Development of the Circum-Antarctic Current did not occur until the middle to late Oligocene when final separation occurred south of the South Tasman Rise, although initial sea-floor spreading between Australia and Antarctica commenced in the late early Eocene. Before the late Oligocene an erosive western boundary current flowed northwards through the Tasman and Coral Sea areas creating a regional unconformity centered near the EoceneOligocene boundary (Leg 21). When circum-Antarctic flow was established in the late Oligocene, a regional Neogene unconformity formed south of Australia and New Zealand, and sedimentation recommenced in the northern Tasman-Coral Sea area. This was due to the western boundary flow which earlier passed through the region and was largely diverted to the area east of New Zealand and into the Tonga Trench. A world-wide Oligocene unconformity was created by a major change in bottom-water circulation, in turn caused by increased bottom-water production related to the onset of substantial Antarctic glaciation near the Eocene-Oligocene boundary. The separation of Australia from Antarctica led to a fundamental change in the world's oceanic circulation and its climate that marks the onset of the modern climatic regime.
\end{abstract}

\section{INTRODUCTION}

One of the objectives of DSDP Leg 29 was to determine the evolution of the Circum-Antarctic Current south of Australia and New Zealand, and to decipher its effects on Cenozoic deep-sea sedimentation in the Southern and South Pacific oceans. Although several drilling sites (Figure 1) were selected to evaluate the development of this major current system, all the sites proved valuable in establishing the general sedimentary patterns and the factors that controlled them.

\footnotetext{
'Graduate School of Oceanography, University of Rhode Island, Kingston, Rhode Island.

${ }^{2}$ Lamont-Doherty Geological Observatory of Columbia University, Palisades, New York.

${ }^{3}$ New Zealand Geological Survey, Christchurch, New Zealand.

‘New Zealand Geological Survey, Lower Hutt, New Zealand.

SUniversity of Adelaide, Adelaide, Australia.

${ }^{6}$ Hungarian Geological Survey, Budapest, Hungary.

${ }^{7}$ University of Rhode Island, Kingston, Rhode Island.

University of Canterbury, Christchurch, New Zealand.

${ }^{9}$ University of Hawaii, Honolulu, Hawaii.

${ }^{10}$ U.S. Geological Survey, Menlo Park, California.

"Institut for Historisk Geologi, Copenhagen, Denmark.
}

The Circum-Antarctic Current is of great oceanographic and climatic importance because it transports more than $200 \times 10^{6}$ cubic meters of water per second, probably the largest volume transport of any ocean current (Gordon, 1967, 1973; Reid and Nowlin, 1971; Callahan, 1971). Furthermore, the Circum-Antarctic Current circulates completely around the Antarctic continent and is the only current that mixes the waters of all oceans. High velocity flow in the surfáce waters of the Southern Ocean extends to the sea floor with relatively small attenuation (Gordon, 1973), providing erosive capabilities which have important geological implications because the current system has shown dynamic changes in the past.

The combined effects of plate tectonic movements at high southern latitudes and Antarctic glacial development during the last $60 \mathrm{~m} . y$.(almost the entire Cenozoic) have led to the formation of the present CircumAntarctic Current. Initial development of the CircumAntarctic Current resulted from the opening of the final constricting region south of Australia. Earlier separations had already occurred south of New Zealand and in the Drake Passage south of South America. Furthermore, initiation and intensification of Antarctic 


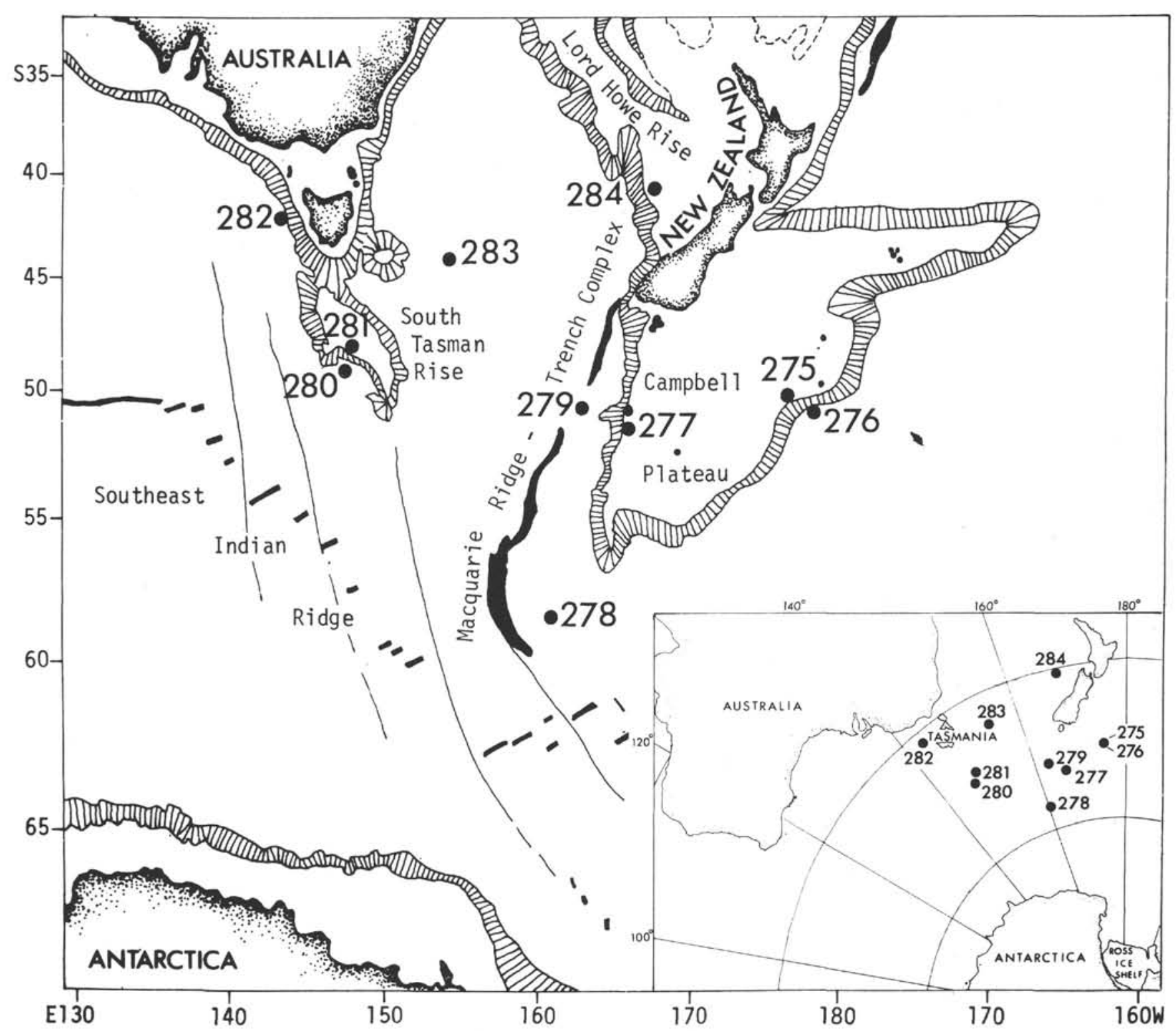

Figure 1. Location of sites drilled during DSDP Leg 29.

glaciation produced important meteorological and oceanographic characteristics of the region, such as the production of Antarctic Bottom Water, which have profoundly affected the deep-sea environment.

\section{BOTTOM CURRENT CIRCULATION IN THE SOUTHWESTERN PACIFIC}

Bottom current circulation in the region south of Australia and New Zealand has been summarized by Gordon (1973), and in the southwestern Pacific region (Tasman Sea) by Warren (1973). The most striking feature of the Circum-Antarctic Current in the Indian and Pacific Ocean regions is the relationship of the water-mass structure to bottom topography (Gordon, 1973). South of Australia, the east-flowing current axis parallels the northern flank of the mid-ocean ridge. A weak current over the southern flank often flows towards the west. Near the southern end of the southeast Indian Ridge, a major flow of bottom water crosses the ridge from the South Indian Basin into the South Tasman Basin. Substantial bottom-water flow from the South Australian Basin is deflected south of the South Tasman Rise, and into the southern part of the Tasman Basin (Figure 2). Presently, bottom-water flow in the deep Tasman Sea is extremely sluggish (Warren, 1973) and northern flow of the bottom water is highly restricted due to the near complete topographic closure of the northern Tasman Basin.

South of New Zealand the Circum-Antarctic Current passing through narrow gaps in the ridge at $54^{\circ} \mathrm{S}$ and branches at the Macquarie Ridge with two filaments 


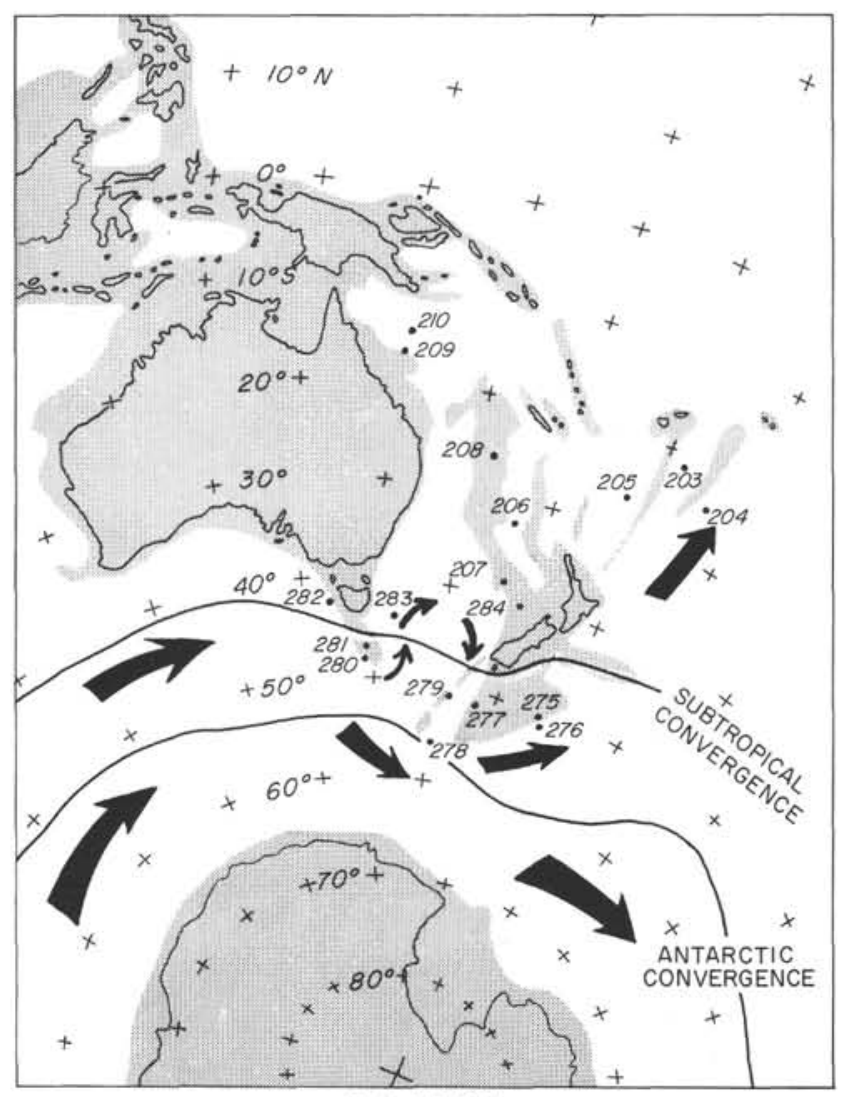

RECENT

Figure 2. Map of general circulation patterns of recent bottom waters of the Australasian-Antarctic area. Arrows represent bottom-current directions (after Gordon, 1971).

$56^{\circ} \mathrm{S}$, and one flowing around the southern end of the ridge. The bulk of the deep bottom-water continues to follow the northern flank of the mid-ocean ridge (Albatross Cordillera) in the South Pacific. However, the northern filaments appear to merge into a jet-like northeast current over the southern flank of the Campbell Plateau (Gordon, 1973). This deep bottom water continues northward as an extensive western boundary current immediately to the east of the New Zealand Plateau, and northward in the TongaKermadec Trench (Warren and Voorhis, 1970; Warren, 1973) with sustained velocities up to $28 \mathrm{~cm} / \mathrm{sec}$ (Gordon, 1973). Thus, major bottom-water activity at present occurs throughout the region that was drilled during Leg 29. Major bottom currents in the South Tasman Basin region result from South Australian Basin currents which are deflected southward around the South Tasman Rise that combine with currents from the south Indian Basin (Figure 2). This is the area of a major erosional surface marked by a vast manganese pavement (Watkins and Kennett, 1972). Further east, on the flank of the Campbell Plateau, seismic profiling records show evidence of extensive erosion by a westernboundary current (see fig. 7 in Chapter 43 , this volume) which extends conspicuously up into the shallow waters of the Campbell Plateau. Thus, there is substantial geological and geophysical evidence to support both deep- and shallow-water erosion resulting from highvelocity bottom currents in the region.

\section{STRUCTURAL HISTORY OF THE SOUTHWEST PACIFIC AND SOUTHWEST INDIAN OCEAN REGION}

Geophysical reconstructions of the southwestern Pacific and the Australia-Antarctica regions have been largely determined by magnetic anomaly patterns (Figure 3). The oldest identifiable magnetic anomalies in the southwest Pacific region are approximately 80 m.y. old and occur along the southwest margin of the Campbell Plateau (Christoffel and Falconer, 1972). Sea floor of approximately the same age is thought to occur on both margins of the Tasman Sea beyond Anomaly 32 (Hayes and Ringis, 1973). Anomalies adjacent to New Zealand record the separation of New Zealand from Australia and Antarctica 60-80 m.y. ago, forming the Tasman Sea between Australia and New Zealand, while Australia remained firmly connected with Antarctica. Approximately 55 m.y. ago spreading ceased in the Tasman Sea region and Australia detached from Antarctica and commenced drifting northward toward its present position (Weissel and Hayes, 1972). The initial Antarctic-Australia rift formed at right angles to the magnetic lineations on the Tasman Sea floor (Figure 3). From about 50 m.y. ago to the present, the spreading center south of New Zealand appears to have remained mid-way between New Zealand and Antarctica and the Tasman Sea spreading center has remained inactive.

The South Tasman Rise is a feature of major importance in the Southern Ocean. Site 281, located on the southern part of the rise, bottomed in middle Paleozoic mica schist, thus proving the continental nature of the rise (Ovenshine, Csejsey,.Smith, and Andrews, Chapter 40 , this volume). The fact that the South Tasman Rise is continental and not formed by post-rift volcanism has important implications to the paleooceanography of the region, since the Circum-Antarctic Current could not have formed until the South Tasman Rise (rather than Tasmania) cleared the northern tip of Victoria Land. This obstruction was not cleared until well after the initial rifting. The spreading between Australia and Antarctica that commenced in the late early Eocene created a barrier to migration of land animals and resulted in the biogeographic isolation of Australia (Ravin and Axelrod, 1972; McGowran, 1973).

\section{UNCONFORMITIES}

One of the most important results of drilling in the north Tasman-Coral Sea regions (Leg 21) was the discovery of a consistent intra-Oligocene unconformity (Figure 4) (Kennett et al., 1972; Edwards, 1973; Burns, Andrews, et al., 1973). The unconformity is present in 


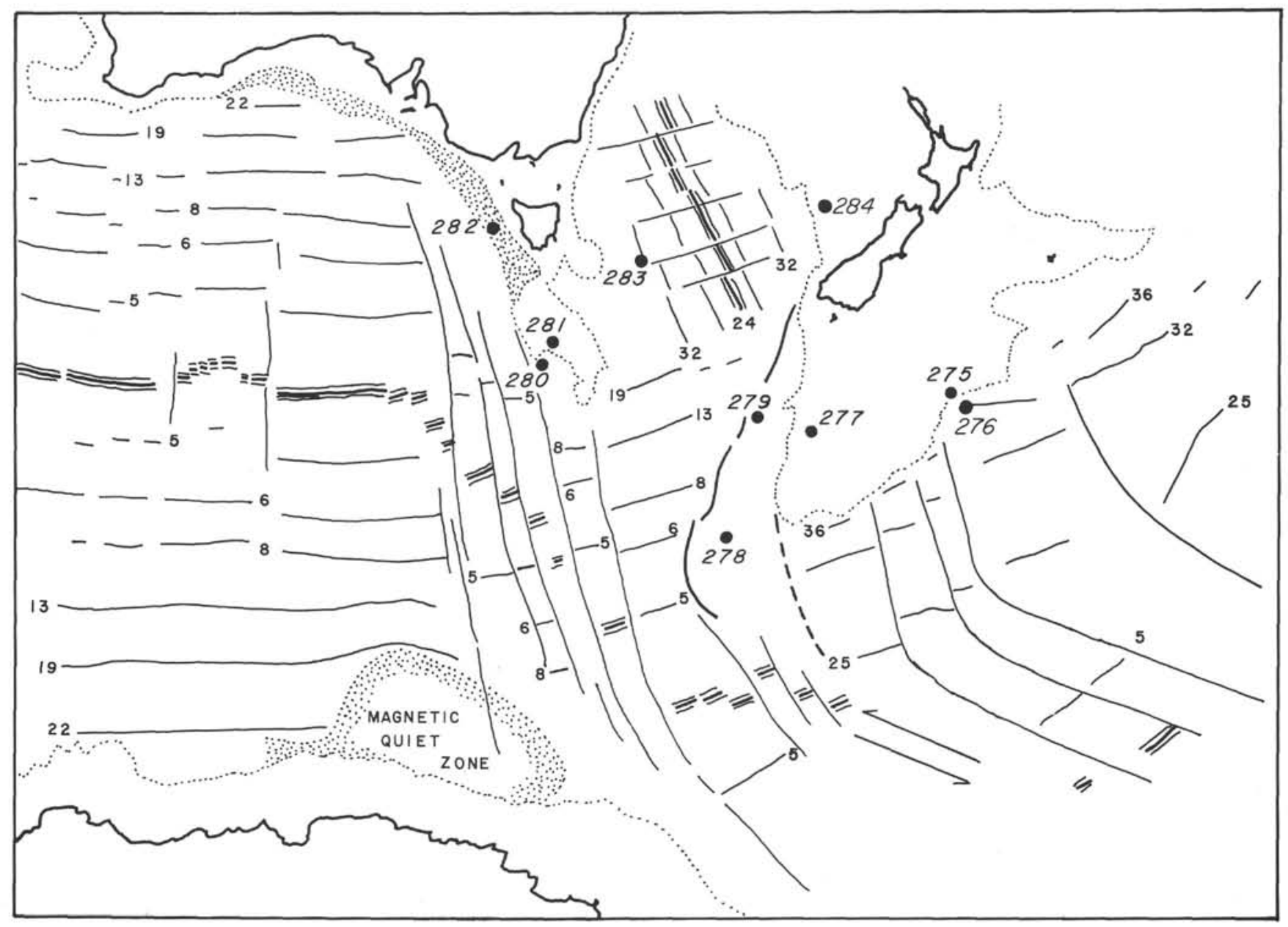

Figure 3. Magnetic anomaly patterns in the oceans between Australia, New Zealand, and Antarctica, determined for the area southwest of New Zealand by Christoffel and Falconer (1972); the Tasman Sea by Hayes and Ringis (1973), and the southeast Indian Ocean by Weissel and Hayes (1972). Location shown of sites drilled during DSDP Leg 29.

sections from both ridges and basins in present water depths varying from 1400 to 5463 meters. In all cases the unconformity includes part of the late Eocene through to the early part of the middle Oligocene, thus spanning 10 to 15 m.y. (Berggren, 1971). The main phase of the erosion appears to have occurred close to the EoceneOligocene boundary (Figure 4). Little evidence exists for tectonic changes associated with the disconformity. Also as recognized by Carter and Landis (1972), this same disconformity, or a similar feature, seems to be present in South Australia (Ludbrook, 1967; Brown et al., 1968), in Papua-New Guinea (Thompson, 1967; Davies and Smith, 1971; Rickwood, 1968), in the Solomon Islands (McTavish, 1966), in Fiji (Rodda, 1967), in New Caledonia (Lillie and Brothers, 1970), and New Zealand (Edwards, 1973). This feature has been referred to as the Marshall Paraconformity by Carter and Landis (1972). The regional unconformity was considered by Kennett et al., (1972) to be the result of deep-sea erosion resulting from increased Antarctic bottom-water supply, which in turn expressed a critical level of glacial development on Antarctica. An older regional disconformity in the Tasman Sea is centered near the Paleocene-Eocene boundary (Edwards, 1973). The presence of Paleogene unconformities in the Tasman Sea region compared with uninterrupted Neogene deposition (last 22.5 m.y.), was interpreted by Kennett et al. (1972) to be the result of major paleooceanographic changes during the Oligocene, in turn related to development of the Circum-Antarctic Current. Three hypotheses suggested to explain the widespread unconformity differ primarily in the direction of the erosive bottom-water flow.

The ten sites drilled during Leg 29 south of Australia and New Zealand revealed a distinctly different sedimentary record. Their record is difficult to interpret (Figure 5), but in general the Neogene and part of the Oligocene are missing in disconformities whereas the 


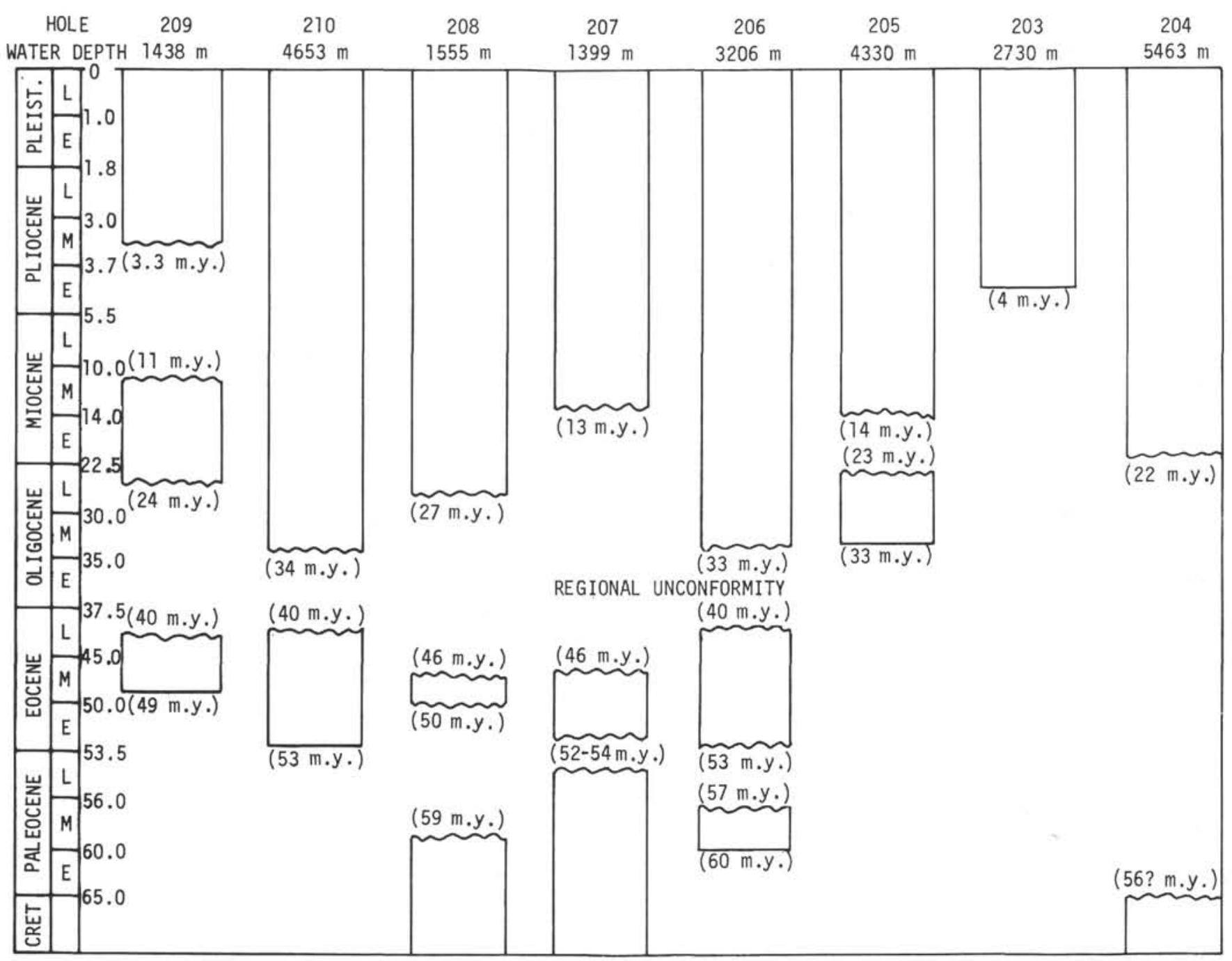

Figure 4. Ages of sediments (m.y.B.P.) of sites drilled during DSDP Leg 21 in the southwest Pacific. Figures in parentheses, outside the columns, are assumed ages of strata either side of unconformities or at the bottom of holes (after Kennett, 1973). The regional unconformity centered in the early Oligocene is shown. Time scale after Berggren (1971).

Paleogene sequences generally tend to be less disrupted by disconformities than the overlying Neogene deposits, except where variable amounts of Oligocene sediments have been eroded.

The relation of each site to deep-sea bottom topography is critical in the evaluation of the regional paleooceanographic patterns. For instance, Site 278 is located on the east side of the Macquarie Ridge which appears to protect the site from the full force of CircumAntarctic Current flow. As a result the sedimentary sequence of Site 278 is relatively continuous throughout compared with adjacent sites. Extensive disconformities present in Sites 275, 276 and 277 (Neogene) result from extremely active western boundary current erosion close to the base of the Campbell Plateau, extending upwards to the shoulder of the plateau. A major disconformity occurring in Site 275 includes the entire Cenozoic and some of the Late Cretaceous. Site 281 on the South
Tasman Rise contains a,complete Neogene sedimentary sequence and is the only site drilled during Leg 29 containing the Oligocene unconformity as seen in the north Tasman Sea and Coral Sea regions (Leg 21). The sedimentary sequence on the South Tasman Rise is almost completely the opposite of the sequences found in the deep-water sites (280 and 282) to the south and northwest. In these sequences the Eocene, and at least the early Oligocene, are uninterrupted sequences of marine terrigenous sediments, while the middle or late Oligocene to present is almost completely absent due to disconformities. In the south Tasman Sea (Site 283) the Oligocene to present record is almost completely absent in disconformity while the Eocene and Paleocene are well represented.

In general, the history of deep-sea deposition in the north Tasman Sea and Coral Sea regions (Leg 21) is the reverse of that in the south Tasman Sea and Southern 


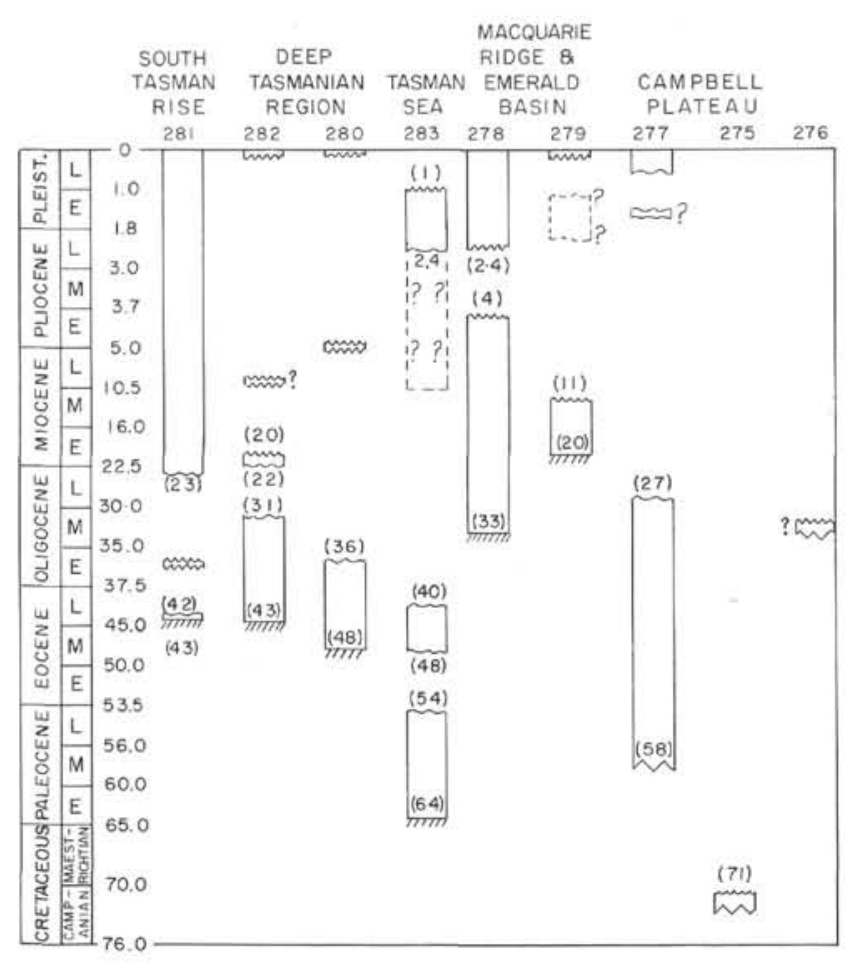

Figure 5. Ages of sediments (m.y.B.P.) of sites shown on Figure 1 drilled during DSDP Leg 29. Figures in parentheses are assumed ages of strata either side of unconformities or at the bottom of holes. Basement is indicated by hachures. Time scale after Berggren (1971).

Ocean regions (Leg 29). In the more northern regions the Paleogene record is dissected by regional unconformities representing intervals of erosion separated by episodes of deposition. The Neogene of the region is characterized by essentially undisturbed deep-sea sedimentation with little erosion. In the Southern Ocean area, however, the Paleogene is recorded in relatively continuous sequences while the late Oligocene to present record has mostly been removed by deep-sea erosion.

\section{SEDIMENTARY CHANGES DURING CENOZOIC}

The history of sedimentation in Leg 29 sites records gradual evolution of the southwest Pacific Basin, the Tasman Basin and the southeast Indian Ocean. The sedimentary succession also reflects major paleocirculation changes that have resulted from the development of these ocean basins. Regional trends of the Cenozoic sediments throughout the region have been summarized in detail by Andrews et al. (Chapter 43, this volume) and Andrews and Ovenshine (Chapter 31, this volume). With the exception of rare occurrences of detrital sand or glauconitic sand, these sediments can be grouped into three facies: terrigenous silt and clay, siliceous ooze, and calcareous ooze-chalk. At several sites these facies succeed each other in this order (Figure 6). During initial rifting the continental regions were closer together and circulation was relatively sluggish. This resulted in deposition of the terrigenous silt and clay facies. The age of this facies is diachronous throughout the region reflecting different ages for the initiation of the basins. Sluggish circulation occurred during the Late Cretaceous in the vicinity of the Campbell Plateau (southwest Pacific Ocean), during the Paleocene and Eocene in the Tasman Sea Basin, and during the Eocene and Oligocene in the southeast Indian Ocean between Australia and Antarctica (Andrews et al. Chapter 43, this volume). With continued sea-floor spreading and increased basinal development, more open-ocean conditions developed, terrigenous sediment sources became more distant and increased biogenic productivity gave rise to late Paleogene biogenic ooze. This, in general, is succeeded in the deep basins and on the shallow-water Campbell Plateau by a poorly represented Neogene sequence highly disrupted by one or several major disconformities reflecting highly active bottom currents.

The Circum-Antarctic Current is the dominating factor in southwestern Pacific sedimentation patterns. As this current system could not have developed until inter. connecting deep basins had formed throughout the entire area south of Australia and the Tasmanian region, the sites drilled adjacent to Tasmania are the most critical in evaluating the sedimentary changes resulting from the initial evolution of the basins that eventually led to the development of the Circum-Antarctic Current. The sedimentary succession at Sites 280, 281, and 282 clearly records early basinal evolution, the evolution of oceanic conditions, and finally the development of the Circum-Antarctic Current itself (Figure 6).

Site 280 is located in deep water south of the South Tasman Rise and the sequence most clearly reflects basinal and circum-Antarctic evolution. The initial Eocene sediments are terrigenous silt and clay facies, deposited at a basin margin relatively near a source area of detrital sediments rather than near the center of the basin. The lack of primary sedimentary structures and poor sediment sorting suggests sluggish bottom-water circulation. However, the wide occurrence of burrow mottling indicates that a moderately diverse infauna inhabited the bottom. Very high organic content indicates that the basin was also rather poorly oxygenated during much of the deposition. Relatively high sedimentation rates in this deep basinal area reflect the nearby source of the detrital sediments. The very low biogenic content of the early sediment within this basin probably indicates a very low siliceous productivity during the middle and late Eocene. However, higher in the terrigenous silt-clay facies near the Eocene-Oligocene boundary, siliceous microfossils (especially diatoms) are increasingly diverse, abundant, and well preserved. The terrigenous silt and clay facies grades up into Oligocene siliceous oozes in which well-preserved diatoms are dominant, indicating an increase of productivity resulting from open-ocean circulation and upwelling commencing in the latest Eocene and continuing into the Oligocene. At the time decreased deposition of 


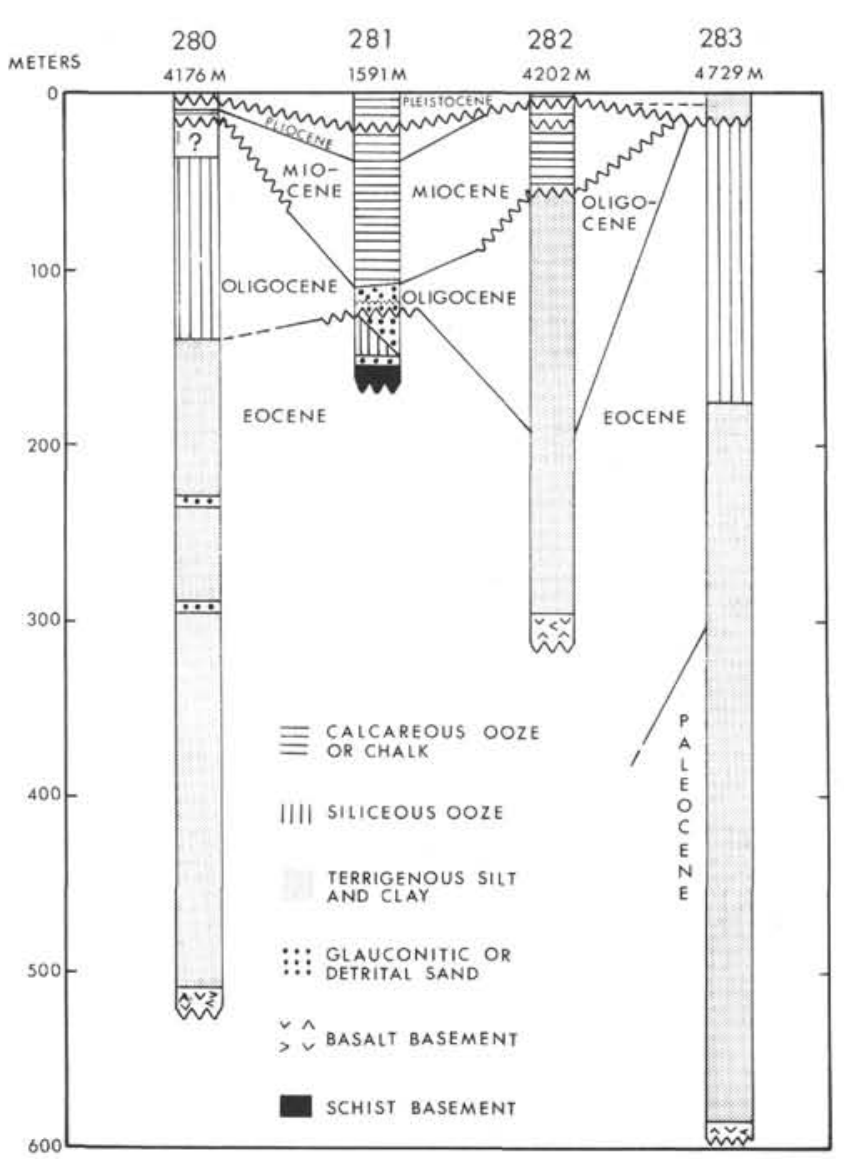

Figure 6. Simplified stratigraphy for four sites drilled near Tasmania. Unconformities indicated.

detrital sediments occurred associated with a reduction in sedimentation rates. This probably reflected movement of the depositional site away from the source of supply.

The record of continued sedimentation in the Paleogene is abruptly terminated at the beginning of the Neogene. The near absence of most of the Neogene is due to the development of high velocity deep-sea bottom currents through the area. This almost certainly reflects the development of intense circum-polar flow south of the South Tasman Rise. Clay mineralogical facies also show that there was no deep oceanic connection between the basins on either side of the South Tasman Rise until the mid-late Oligocene (Gostin and Moriarty, Chapter 34 , this volume).

The sedimentary succession on the shallow-water South Tasman Rise (Site 281) also records major paleocirculation changes in this area (Hampton, Chapter 33, this volume). During the late Eocene, although basin development had not evolved enough to develop deep-water circulation south of the South Tasman Rise, a shallow-water connection did link the southwest Pacific with the southeast Indian Ocean across the South Tasman Rise. Benthonic foraminiferal assemblages indicate that this shallow-water connection was no deeper than 200-300 meters. Despite the shallowwater connection between the oceans, the lack of strong bottom currents indicates that no shallow protoCircum-Antarctic Current was then in existence. Toward the end of the Eocene, bottom currents increased to transportational or erosional intensity, producing disconformities or highly condensed sequences involving most of the Oligocene and late late Eocene. These can be correlated with the regional Coral and Tasman Sea unconformity. Unlike Sites 280 and 282, an uninterrupted Neogene sedimentary record of calcareous ooze is recorded.

The effects of intensified circulation during the Oligocene to late Eocene are recorded at Site 281 by the prolonged period of nondeposition, or highly reduced rates of sedimentation when glauconites were deposited. Reinitiation of sediment deposition in the earliest Miocene reflects the diminishing current effects as the rise moved northward and circum-Antarctic flow established its position south of the South Tasman Rise, similar to the present day. Much of the South Tasman Rise then became a quiet area of pelagic biogenic sedimentation, forming the early Miocene to Recent foraminiferal-nannofossil oozes.

About $300 \mathrm{~km}$ south of the South Tasman Rise, the sea-floor topography of an 800-meter-thick sediment section exactly parallels a rough basement surface, suggesting deposition of the entire sequence in bottomwater conditions with zero energy (fig. 6, Chapter 42). Alternatively, the sediment may have been originally deposited on a fairly flat basement and was later faulted extensively. If the tectonic explanation is not correct, a major anomaly exists because the region should have been marked by dynamic bottom conditions during deposition of the sediment. Other complications are implicit in the profiler section (fig. 11, Chapter 42), where an east-west graben separating the South Tasman Rise from Tasmania may have allowed the passage of bottom-water from the southeast Indian Ocean to the Tasman Sea at some time earlier than the middle to late Oligocene. It is therefore possible only to generalize on major movements of water masses. The exceedingly complex formation of transform fault zones, associated ridges, and the east-west grabens do not allow a detailed history to be determined of the early phases of bottomwater breakthrough.

\section{PALEOGENE CLIMATES AND GLACIAL HISTORY OF ANTARCTIC-OCEANOGRAPHIC IMPLICATIONS}

The glacial history of Antarctica has had farreaching effects on the paleocirculation characteristics of the world's oceans, especially deep-ocean circulation. At times of intensified Antarctic glacial activity, enhanced sea-floor erosion occurs, resulting primarily from intensified deep-sea circulation (Watkins and Kennett, 1972; Johnson, 1973).

Global evidence indicates that the interval near the Eocene-Oligocene boundary was one of the most important periods of climatic cooling during the Cenozoic, and that the Oligocene represents a prolonged period of 


\section{J. P. KENNETT ET AL.}

relatively cool climates (Table 1). The oxygen isotope curves of Devereux (1967), Douglas and Savin (1973), and Shackleton and Kennett (Chapter 17, this volume) all indicate a major cooling closely associated with the Eocene-Oligocene boundary. At or near the beginning of the Oligocene, a dramatic decrease in temperature apparently reduced the surface temperature at the Antarctic coast close to freezing. This would have produced glaciers at sea level if precipitation was adequate and would have led to extensive sea-ice production, and hence represents a critical stage in the development in Antarctic glacial history (Shackleton and Kennett, Chapter 17, this volume). This event also marks the onset of a deep-water circulation dominated, as today, by the formation of bottom water at temperatures close to freezing around the Antarctic continent. Although the oxygen isotope records imply that extensive Antarctic glaciation started at the beginning of the Oligocene, they also strongly suggest that if an ice-sheet were present during the Oligocene, it would not have been more than a small fraction of its present-day thickness. (Shackleton and Kennett, Chapter 17, this volume) This conflicts with the studies of LeMasurier (1972) who believes that dated hyaloclastites in Marie Byrd Land show that a thick ice-sheet in West Antarctica has been continuously present since Eocene time. Evidence of probable Antarctic glaciation during the Oligocene has already been recorded by Margolis and Kennett (1970, 1971) from the discovery of ice-rafted debris in highlatitude Southern Ocean cores. Drilling during DSDP Leg 28 in Antarctic water adjacent to East Antarctica and within the Ross Sea region has shown that extensive glaciation began on the Antarctic continent, at least by early Miocene ( 20 m.y.), and perhaps locally in the late Oligocene (Hayes et al., 1973). Geitzenauer et al. (1968) and Margolis and Kennett $(1970,1971)$ have recorded

TABLE 1

Cenozoic Sequence of Some Major Antarctic Climatic, Glacial, and High Southern Latitude Oceanographic Events

\begin{tabular}{|c|c|c|}
\hline $\begin{array}{c}\text { Age } \\
\text { (m.y.B.P.) }\end{array}$ & Epoch & Event \\
\hline 0.7 & Late Pleistocene & $\begin{array}{l}\text { Further increase in upwelling and biogenic producti- } \\
\text { vity at Antarctic Convergence; increase in ice-rafting. }\end{array}$ \\
\hline 2.6 & Late Pliocene & $\begin{array}{l}\text { Development of Northern Hemisphere glaciation } \\
\text { (Shackleton and Kennett, Chapter 17, this volume). }\end{array}$ \\
\hline $4.2-\sim 5$ & $\begin{array}{l}\text { Late Miocene- } \\
\text { early Pliocene }\end{array}$ & $\begin{array}{l}\text { Development of Antarctic ice sheet much thicker than } \\
\text { present (Shackleton and Kennett, Chapter 20, this } \\
\text { volume): major regression (Kennett, 1967): global } \\
\text { marine cooling (Kennett and Vella, Chapter 18, this } \\
\text { volume): development of West Antarctic ice sheet } \\
\text { (Mercer, 1972): major increase in upwelling and bio- } \\
\text { genic productivity at Antarctic Convergence. Increase } \\
\text { in ice rafting. }\end{array}$ \\
\hline $10-13$ & $\begin{array}{l}\text { Middle Miocene- } \\
\text { early late Miocene }\end{array}$ & $\begin{array}{l}\text { Development of major ice cap on East Antarctica. } \\
\text { First recorded ice rafting in northern Antarctic waters } \\
\text { south of New Zealand (Site 278). }\end{array}$ \\
\hline 22 & Early Miocene & $\begin{array}{l}\text { Initiation of Antarctic Convergence with low degree } \\
\text { of upwelling. }\end{array}$ \\
\hline $25-30$ & Late Oligocene & $\begin{array}{l}\text { Development of Circum-Antarctic Current and related } \\
\text { major changes in deep-sea sediment patterns. }\end{array}$ \\
\hline $22-38$ & Oligocene & $\begin{array}{l}\text { Prolonged Antarctic glaciation but no substantial ice } \\
\text { sheet formed. Prolonged active bottom currents and } \\
\text { deep-sea erosion in many areas. Increased calcareous } \\
\text { biogenic productivity and accumulation in central } \\
\text { Pacific (Heath, 1969; Moore, 1972). }\end{array}$ \\
\hline 38 & $\begin{array}{l}\text { Eocene-Oligocene } \\
\text { boundary }\end{array}$ & $\begin{array}{l}\text { Major global cooling; development of Antarctic glacia- } \\
\text { tion at sea level; extensive production of sea ice and } \\
\text { Antarctic bottom water; development of present ther- } \\
\text { mo-haline oceanic circulation; enhanced deep-sea ero- } \\
\text { sion; some iceberg production; major change in abyssal } \\
\text { benthic faunas. Large abrupt depth increase in calcium- } \\
\text { carbonate compensation depth (Heath, 1969; Van } \\
\text { Andel and Moore, 1974). }\end{array}$ \\
\hline $38-53$ & Eocene & $\begin{array}{l}\text { Temperate climates; any Antarctic glaciation restricted } \\
\text { to higher elevations. Ice-rafted sediments to southeast } \\
\text { Pacific (Geitzenauer et al., 1968; Margolis and Kennett, } \\
\text { 1971). }\end{array}$ \\
\hline
\end{tabular}

Note: Chronology after Berggren (1971). Most events recognized by various authors studying Leg 29 material. See text for reference sources other than those indicated. 
ice-rafted debris in Eocene deep-sea cores from the Antarctic region. In the southernmost subantarctic site drilled south of New Zealand, Site 278, ice-rafted debris does not appear until the middle Miocene (Margolis, Chapter 30, this volume). Thus, the initial appearance of ice-rafted debris appears to be diachronous and depends on the complex set of factors including paleocirculation patterns, location of glaciers on the continent, and distance from the Antarctic continent.

According to Shackleton and Kennett (Chapter 17, this volume), the isotope record in subantarctic cores indicates a relatively rapid development on the Antarctic continental ice sheet to more or less present thickness between the early middle Miocene and the early late Miocene (Table 1). This corresponds closely with the evidence that substantial ice rafting did not occur until well within the Neogene (Margolis, Chapter 30, this volume; Hayes et al., 1973). Kemp (1972) and Frakes and Kemp (1973) have summarized the paleobotanical evidence for Paleogene global climates, and consider that most of the evidence suggests warm humid conditions throughout much of the Eocene, becoming much cooler sometime during the Oligocene. Wolfe and Hopkins (1967) consider that vegetation changes in the early to middle Oligocene from northwestern United States and Alaska require a minimal drop in temperature of some $7^{\circ} \mathrm{C}$ in mean annual temperature.

To resolve the apparent conflicting evidence of Eocene ice rafting from Antarctica and paleontological evidence suggesting a limited ice development in the Antarctic region during at least part of the Eocene, with more temperate conditions occurring in more northerly Antarctic coastal regions (Table 1). This rapidly changed at or near the Eocene-Oligocene boundary when temperatures in the coastal waters of Antarctica decreased to about freezing. A considerable cooling associated with the Eocene-Oligocene boundary has been previously recognized by Edwards (1968) based on changes in calcareous nannofossils and by Jenkins (1968) on planktonic foraminifera in New Zealand sequences. Hornibrook (1971) has summarized the New Zealand evidence for Eocene and Oligocene climates and considers the significant temperature fall across the Eocene-Oligocene boundary to be valid based on overall evidence. However, he points out that discrepancies occur in interpretations based on terrestrial and benthic marine fossils. Jenkins (in press) has also discussed the paleotemperature drop near the Eocene-Oligocene boundary as it has affected the planktonic foraminiferal faunas. He considers that marked extinctions of planktonic foraminifera did not occur as a single event close to the Eocene-Oligocene boundary. Instead a succession of extinctions commenced during the latest Eocene and continued across the Eocene-Oligocene boundary. It is clear that they resulted from major paleoclimatic and paleo-oceanographic cooling. Succeeding faunas throughout the Oligocene are of low diversity and reflect rather prolonged cool conditions thus supporting the oxygen isotopic evidence of Shackleton and Kennett. The diversity of Antarctic planktonic foraminiferal faunas in the Oligocene was ex- tremely low (Margolis and Kennett, 1970, 1971) as well as in the North Pacific subarctic area (Echols, 1973). This indicates that polar waters were particularly cool during the Oligocene, and thus agree with the oxygen isotope evidence.

The most generally accepted theory for the formation of Antarctic bottom water is related to sea-ice formation in the Antarctic region (Fofonoff, 1956; Mosby, 1971). Newly formed, highly saline, and dense water sinks and mixes with warmer deep water to form the highly dense and cold Antarctic bottom water. However, opinions differ over which conditions are ideal for formation of large volumes of Antarctic bottom water. Gordon (1971) suggests that greater volumes of Antarctic bottom water were produced during glacial episodes when ice shelves were well developed. On the other hand, Weyl (1968) has speculated that greater volumes are produced during interglacial episodes when sea-ice development is less permanent and varies on a seasonal basis resulting in greater opportunity for freeze and thaw and hence bottom-water production. Weyl considers that during glacial episodes sea ice is more permanently developed, and thus there is less opportunity for bottom-water production. Some support for Weyl's thesis comes from the work of Schnitker (1974) and Streeter (1973) who have examined changes in abyssal benthonic foraminifera in Pleistocene cores.

The regionality of the unconformity centered near the Eocene-Oligocene boundary in the Coral and Tasman Sea regions indicates enhanced deep-sea erosion caused by Antarctic bottom water production (Kennett, et al., 1972), in turn resulting from increased development of Antarctic sea ice due to the major cooling commencing at or near the Eocene-Oligocene boundary (Shackleton and Kennett, Chapter 17, this volume). This led to longterm glaciation during the Oligocene, inferred large production of sea ice, and an increase in deep-sea erosion during much of the Oligocene. Accelerated oceanic turnover also inferred to have occurred during the Oligocene is reflected by increased calcareous biogenic productivity in the central Pacific causing an increase in accumulation rates (Heath, 1969; Moore, 1972). A substantial drop in bottom-water temperature at the Eocene-Oligocene boundary, indicated by oxygen isotope measurements of deep-sea benthonic foraminifera (Shackleton and Kennett, Chapter 20, this volume) is also associated with the initiation of Cenozoic Antarctic bottom water development. The drop in temperature of bottom water at the EoceneOligocene boundary of about $4^{\circ} \mathrm{C}$ (Shackleton and Kennett, Chapter 17, this volume) created major changes in the abyssal benthonic faunas of the world's oceans. Benson (in press) has shown that a major change took place in the abyssal ostracod faunas close to the Eocene-Oligocene boundary, which he considers to reflect the origin of the present cold bottom-water circulation. Douglas (1973) also reports a major faunal turn-over in abyssal benthonic foraminifera in the late Eocene and early Oligocene, marking a rapid cooling of bottom water. Major deep-sea circulation changes of the world's oceans, beginning at the Eocene-Oligocene 
boundary are also associated with major deepening, in the earliest Oligocene, of the calcium carbonate solution boundary (Heath, 1969; Van Andel and Moore, 1974), further emphasizing the magnitude of the paleooceanographic event that occurred at or close to the Eocene-Oligocene boundary (Table 1).

\section{WORLD-WIDE OLIGOCENE UNCONFORMITY}

The regional Oligocene unconformity in the Tasman Sea and Coral Sea region is represented in DSDP sites throughout the Atlantic, Pacific, and Indian Ocean areas. Its oceanic regionality was recognized by Rona (1973) who analyzed the record of hiatuses in all DSDP sites through Leg 25. The hiatuses are in general of longer duration in the western oceanic basins indicating formation by bottom current erosion (Pimm and Hayes, 1972). An additional regional unconformity of Paleocene age in the southwest Pacific recognized by Edwards (1973) has also been recognized by Rona to be of global extent. However, as pointed out by Edwards (1973) and Rona (1973), the Paleocene hiatus is less pronounced than the Oligocene hiatus. Subsequent drilling during Leg 30 (Andrews, Packham, et al., 1973) has also recorded a hiatus centered over the EoceneOligocene boundary in Sites 288 and 289 located on the Ontong-Java Plateau north of the Solomon Islands in the West Pacific, as well as in Site 287 located in the Coral Sea. The process that caused deep-sea erosion during the Oligocene must account for its vast regionality. Such a mechanism was proposed by Kennett et al. (1972) who suggested that world-wide climatic cooling during the Oligocene, associated with Antarctic glaciation, was critical in causing extensive bottom-water erosion through intensified circulation such as is known for certain regions during the late Cenozoic (Watkins and Kennett, 1971; Johnson, 1973). This hypothesis is now supported by the oxygen isotope data of Shackleton and Kennett (Chapter 17, this volume) in which the major drop in temperature, close to the Eocene-Oligocene boundary, records the initiation of bottom-water production. This phenomenon can be expected to have produced the required increase in deep-sea circulation to create the observed deep-sea erosion.

The Oligocene hiatus appears to be of greater global extent than any hiatus that has occurred during the late Cenozoic when polar glaciations are known to have been more extensive than during the earlier Cenozoic. It is suggested that the vastness of the Oligocene unconformity reflects much greater Antarctic bottom water production during the Oligocene than during the late Cenozoic and the development in the late Eocene of north Atlantic deep-current circulation (Pimm and Hayes, 1972) which presumably originated in high northern latitudes. In the Antarctic region, Antarctic bottom water may have developed in large volumes during the initial stages of Antarctic glaciation in the Paleogene when ice shelves had probably not developed, and hence there was a larger area for sea-ice development in Antarctic embayments such as the Ross and Weddell seas. It is also possible that greater seasonal variations produced greater sea-ice freeze and thaw. By the late Cenozoic the vast continental ice shelves had developed, thus decreasing the area over which sea ice and bottom water could form. It is also possible that bottom water produced during the Oligocene before the Circum-Antarctic Current development had greater effects in the more northern oceanic areas than during the late Cenozoic when more bottom water probably remained in circum-Antarctic flow. The hiatus is particularly pronounced in sections drilled in DSDP because most sites are selected on topographic highs where sedimentary sections are thinner because of higher susceptibility to current erosion. Thick continuous sequences of Oligocene sediment reworked from topographically higher regions are inferred to occur in deeper basins which are not usually drilled. However, it is possible that much of the eroded biogenic materials would not be redeposited in the original form due to additional dissolution. The Paleocene hiatus (Rona, 1973), possibly centered approximately at the PaleoceneEocene boundary (Edwards, 1973), appears to be associated with global climatic cooling (Shackleton and Kennett, Chapter 17, this volume). Rona (1973) suggested that the more pronounced expression of the Oligocene as compared to the Paleocene hiatus may reflect the development of thermo-haline circulation following present patterns, and also suggested that ocean-circulation changes creating hiatuses in the Paleogene resulted from oceanic volume changes due to volume changes in the mid-oceanic-ridge system. We propose that the Paleogene hiatuses throughout the oceans are more readily explained by climatically induced thermo-haline circulation changes.

\section{SUMMARY OF THE EVOLUTION OF ANTARCTIC PALEOCEANOGRAPHY AND GLACIATION}

The Circum-Antarctic Current would not develop until a barrier-free zone occurred around Antarctica (Gill and Bryan, 1971). Hence, the time that the Drake Passage region opened is crucial, but is still not known. Barker and Griffiths (1972) and Dalziel and Elliot (1971) indicate opening sometime during the Paleogene at the time that the Scotia Sea region was formed. Relationships discovered between the structural history in the Australasian region and major sedimentary distribution changes disclosed by Legs 21 and 29 indicate that the Circum-Antarctic Current developed south of Australia when the constriction formed by Tasmania and the South Tasman Rise had moved north away from Antarctica. This in turn suggests that the Drake Passage opened before final opening south of Tasmania.

The evolution of the Circum-Antarctic Current south of Australia and New Zealand can be traced by a series of maps (Figures 7-10). In the Late Cretaceous and Paleocene, Australia and Antarctica were joined (Weissel and Hayes, 1972) and no Circum-Antarctic Current existed (Figure 7). The Tasman Sea region was expanding (Hayes and Ringis, 1973). Earlier in the Late Cretaceous, terrigenous sediments were initially deposited in restricted basins on the Campbell Plateau which was adjacent to Antarctica. Later within the Late Cretaceous, increasing rich siliceous biogenic sediments 


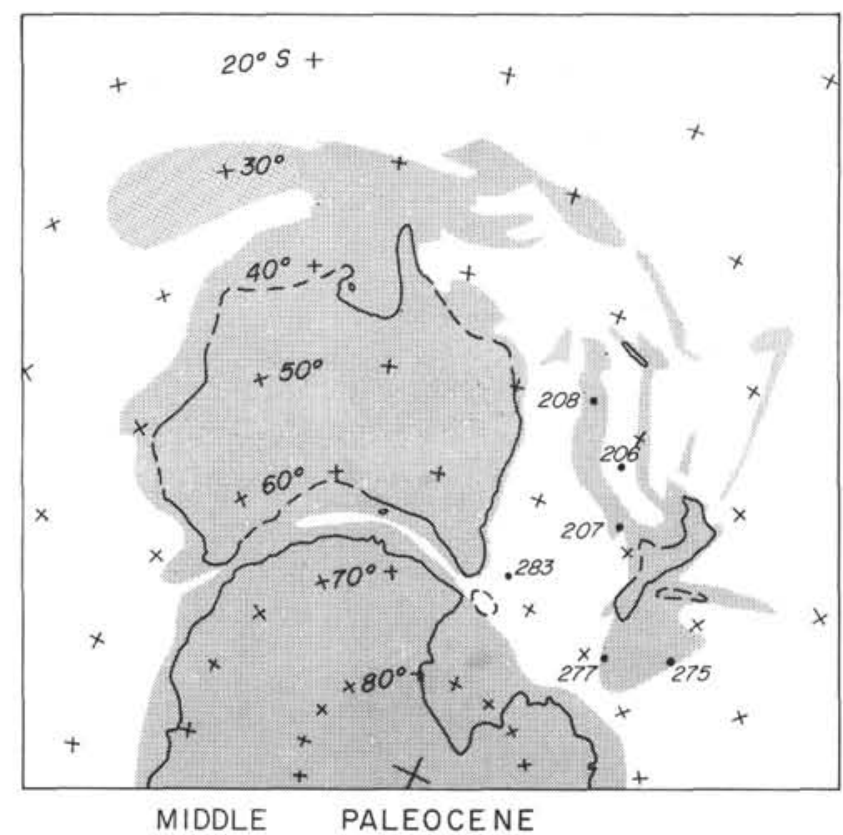

Figure 7. Middle Paleocene reconstruction (58 m.y.B.P.) of Australia, Antarctica and New Zealand, and associated ridges. Reconstruction after Weissel and Hayes (1972) and Hayes and Ringis (1973). Locations are shown of several DSDP sites (Legs 21 and 29).

reflect the development of more oceanic conditions. Relatively low diversity of Late Cretaceous radiolarian faunas at Site 275 (Pessagno, Chapter 27, this volume) supports a high-latitude position of the southern part of the Campbell Plateau although the sediments are not of glacial origin. The lack of calcareous microfossils shows that calcium carbonate dissolution was at very shallow depths like in present-day high-latitude regions (Kennett, 1966).

By the late middle Eocene and late Eocene (Figure 8) a substantial ocean had developed between much of Australia and Antarctica. Spreading appears to have been a diachronous event beginning in the west, propagating eastward with resulting diachronism in sedimentation (McGowran, 1973). In the middle Eocene truly marine conditions first appeared in the Eucla and Otway basins in central southern Australia, with a diachronous west-east trend. These preceded a more extensive late Eocene transgression that spread onto intracratonic areas (Brown et al., 1968). The South Tasman Rise and Tasmania protruded far southward from the main Australian continent and continued to block circum-Antarctic flow. The sea way between Tasmania and Australia remained closed by highlands (Elliot, 1972). Oceanic crust formed in the region southwest of Tasmania and the South Tasman Rise during the late middle to late Eocene (Sites 280 and 282). By

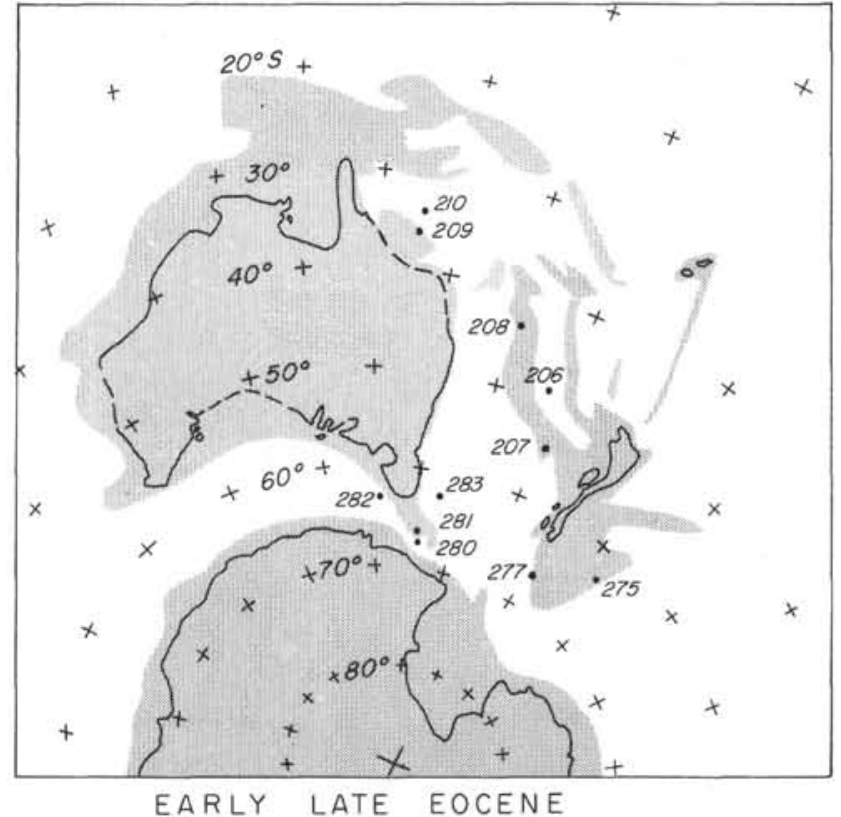

Figure 8. Early late Eocene (45 m.y.B.P.) reconstruction of Australia, Antarctica and New Zealand, and associated ridges. Reconstruction after Weissel and Hayes (1972). No Circum-Antarctic Current had developed by this time.

the late Eocene a very shallow marine connection was established across the South Tasman Rise in the vicinity of Site 281. The shallowness of this marine connection between the southwest Pacific and the southeast Indian oceans prevented the development of active bottom currents, and the sediments show little evidence of dynamic bottom-water conditions. During most of the Eocene, surface-water temperatures in the Southern Ocean were considerably higher than at any time since (Devereux, 1967, Shackleton and Kennett, Chapter 17, this volume). In New Zealand, the warmest episode of the Cenozoic occurred during the late Eocene (Hornibrook, 1971). Glaciation on Antarctica during this time was most likely restricted to high altitudes. The presence of ice-rafted debris and very low planktonic foraminiferal diversity in southwest Pacific deep-sea cores indicate at least localized iceberg development, and thus some glaciation at or near sea level (Geitzenauer et al., 1968; Margolis and Kennett, 1970). About 38 m.y. ago, near the Eocene-Oligocene boundary, the sediment patterns in the southwest Pacific began to be extensively disrupted by bottom-water circulation. This resulted from the development of glacially induced Antarctic bottom-water production, and the commencement of oceanic thermo-haline circulation (Table 1). Resulting active deep-sea erosion continued throughout much of the Oligocene, which was relatively 


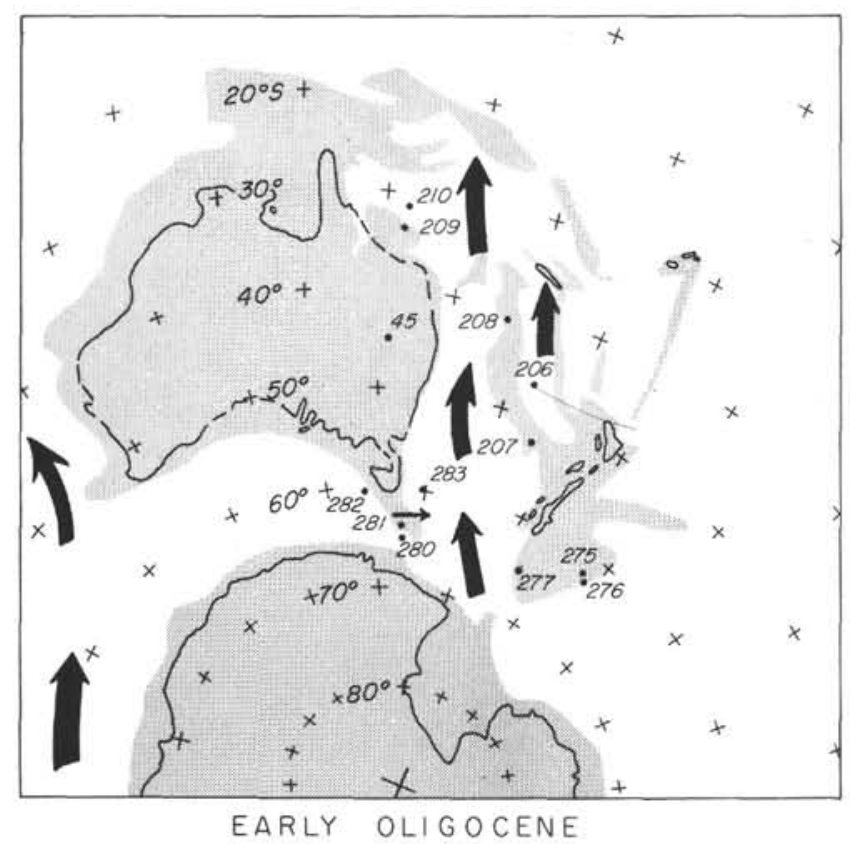

Figure 9. Early Oligocene (37 m.y.B.P.) reconstruction of Australia, Antarctica and New Zealand, and associated ridges (after Weissel and Hayes, 1972) with suggested direction of bottom-water circulation (arrows) northward from Antarctic sources through the Tasman-Coral Sea area and west of Australia. No Circum-Antarctic Current had developed by this time, but currents flowed across the shallow south Tasman Rise.

cool, and formed the Oligocene oceanic hiatus particularly pronounced in the western parts of oceans in areas of more active western-boundary currents. The regional Oligocene unconformity in the Tasman and Coral Sea regions was formed by actively eroding bottom currents derived from the Ross Sea sector of Antarctica flowing northward as a broad western boundary current. During the early to middle Oligocene (Figure 9), despite continued northward movement of Australia from Antarctica, the South Tasman Rise still had not moved sufficiently north to create a circum-Antarctic current. The increasingly oceanic conditions of the deep basins immediately adjacent to Tasmania and the South Tasman Rise were heralded in the Oligocene by the deposition of deep-sea biogenic oozes. Bottom-water circulation was still restricted, and no evidence exists within the early Oligocene of erosion in these deep basins. However, a hiatus or highly condensed sequence, representing the latest Eocene and Oligocene, reflects a prolonged interval of bottom erosion over the shallow-

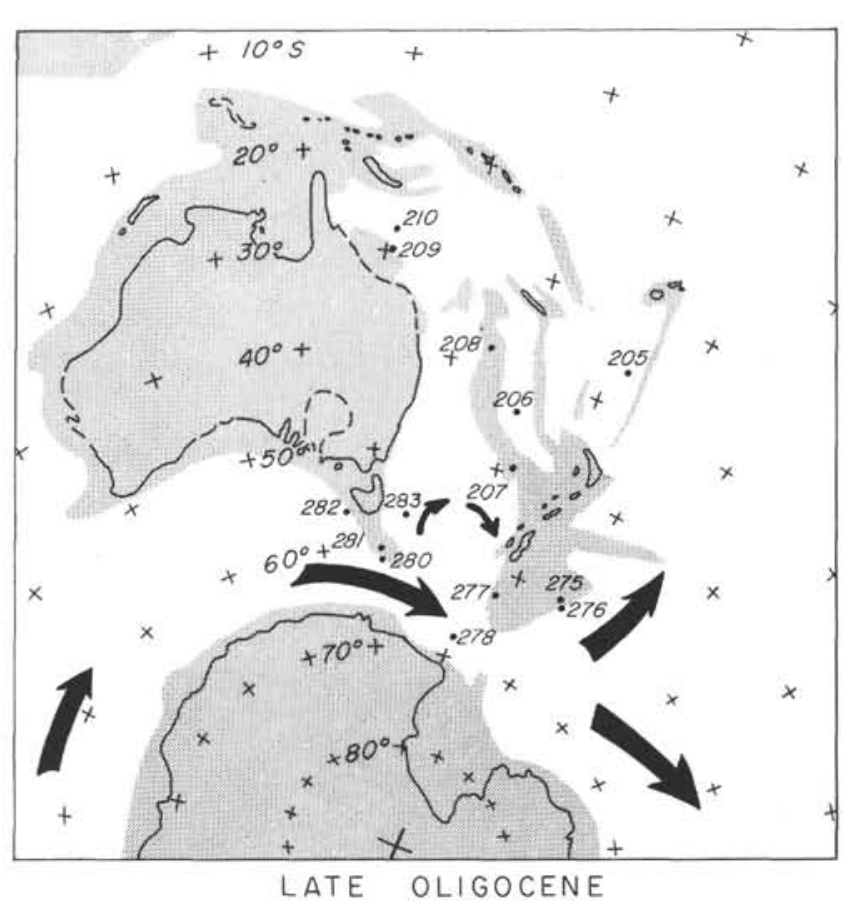

Figure 10. Late Oligocene (30 m.y.B.P.) reconstruction of Australia, Antarctica and New Zealand, and associated ridges (after Weissel and Hayes, 1972) showing the direction of the Circum-Antarctic Current south of Australia and New Zealand and a western-boundary current east of New Zealand. This direction has been retained until the present.

water South Tasman Rise. This hiatus is equivalent to that in the Tasman Sea, Coral Sea, and other oceanic sequences throughout the world, and appears to reflect intensified oceanic circulation resulting from Antarctic glacial development. It is unknown whether a western boundary current flowed northward to the east of New Zealand during the Oligocene as it does today. Continued deposition of calcareous biogenic ooze sequence on the Campbell Plateau (Site 277) records a lack of active bottom currents over this shallow region, and hence possibly, a less intensive western boundary current than in the present day.

Major paleocirculation changes probably occurred north of Australia and New Guinea between the Eocene and Oligocene resulting from the northward movement of Australia. Before the Oligocene, relatively free circulation would have existed north of Australia-New Guinea between the Indian and Pacific oceans. Closure of the deep-sea passageway in this area, beginning in the Oligocene, restricted this circulation (Moberley, 1972). Such a development probably had great influence over the general oceanic paleocirculation patterns (especially 
climate), but apparently had little effect on the deep circulation in the South Pacific and south Indian oceans.

During the middle to late Oligocene, about 25-30 m.y. ago (Figure 10), a drastic change in regional sediment patterns occurred throughout the entire southwest Pacific region and in the Southern Ocean south of Australia and New Zealand. At this time the opening developed between the southern part of the South Tasman Rise and Antarctic creating an active circumAntarctic deep-sea circulation. As a result, the deep basins adjacent to Tasmania and South Tasman Rise have virtually no sedimentary record for the entire Neogene and late Oligocene (the last 30 m.y.). At the time that deep circum-Antarctic circulation developed south of the South Tasman Rise, the influence of bottom current activity over the rise waned. On the Campbell Plateau (Site 277), continuous Paleogene calcareous oozes underlie a major hiatus spanning the latest Oligocene to Pleistocene (Figure 5). This change from deposition to erosion near the Neogene-Paleogene boundary almost certainly resulted from highly active bottom currents over the plateau related to Antarctic current development and the establishment of a highly eroding western boundary current system to the east of New Zealand (Figure 10). The absence of extensive bottom-current erosion in the northern Tasman-Coral Sea regions since the Oligocene is due to the "diversion" of important northward flowing bottom currents from the Tasman Sea region to the eastern side of New Zealand (Figure 10). This diversion could be the result of either the development of topographic barriers in the northern Tasman Sea area or the deflection of potentially northward-flowing bottom currents by the active Circum-Antarctic Current. The Lord Howe Rise had already developed by the Late Cretaceous in the northern Tasman Sea (Kennett et al., 1972). Hence, the development of the Circum-Antarctic Current appears to have largely created the major paleocirculation changes rather than deep-sea topographic changes in the Tasman Sea. Distribution patterns of sediments in the region suggest that no major changes have occurred in the direction of deep-sea circulation since the late Oligocene, although further major changes have occurred in the intensity of bottom-water flow (Watkins and Kennett, 1972) and in the development of the Antarctic Convergence.

Fluctuations in lithology from nannofossil to radiolarian-diatom oozes at Site 278 indicate changes in the location and strength of the Antarctic Convergence. Siliceous-rich oozes record periods when productivity and sedimentation rates were increased by the nearness of the convergence. Oligocene sediments at Site 278 are represented by siliceous nannofossil chalks with very low sedimentation rates. This suggests only weak or nonexistent upwelling at this time and thus probably the absence of a convergence in this region. During the early Miocene ( 22 m.y.B.P.), the first siliceous oozes were deposited in Site 278, and probably reflect increased productivity associated with the early development of the Antarctic Convergence. Upwelling was probably sluggish, however, because sedimentation rates were moderately low. Alternations of siliceous- and carbonate-rich biogenic sediments in the middle Miocene record fluctuations in position of the convergence, although the combination of siliceous and carbonate components suggests that the position did not change greatly. The presence of the Macquarie Ridge may have restricted the movement of the convergence throughout the Neogene because today the convergence is diverted farther south by the ridge. Thus, Leg 29 data indicate that the Antarctic Convergence did not become a prominent feature until after the development of the Circum-Antarctic Current.

The cause of the major climatic cooling near the Eocene-Oligocene boundary leading to increased Antarctic glaciation is not known. Such a cooling could be related to the development of oceanic conditions resulting from the separation of Australia and Antarctica or to increased circulation resulting from the opening of the Drake Passage. Meteorological conditions of the region would be greatly altered, leading to a much stronger west wind drift and providing moisture-bearing winds to the Antarctic continent. The development of the Circum-Antarctic Current itself does not appear to have produced either the initial glaciation or cooler ocean conditions. The oxygen isotope evidence of Devereux (1967) and Shackleton and Kennett (Chapter 17 , this volume), illustrates that the beginning of the Miocene was marked by a substantial warming trend which persisted with fluctuations until the middle Miocene. As a result bottom-water activity throughout the world appears to have waned.

During the middle Miocene ( 13 m.y.B.P.), the major east Antarctic ice sheet began to accumulate rapidly with the buildup essentially complete by the early late Miocene ( 10-12 m.y.B.P.) (Shackleton and Kennett, Chapter 17, this volume). The first recorded ice-rafted debris in Site 278 appears to correspond with this critical glacial development (Margolis, Chapter 30, this volume).

An increase in siliceous productivity that commenced about early Pliocene (5 m.y.B.P.) and has continued to the present day largely indicates an intensification of upwelling associated with the Antarctic Convergence. This intensification is probably related to a critical development of Antarctic glaciation during the late Mioceneearliest Pliocene (Shackleton and Kennett, Chapter 17, this volume). Other areas of the Southern Ocean experienced related increases in deep-sea erosion (Watkins and Kennett, 1972). A drastic increase in sedimentation as revealed in the upper sections of Site 278 indicates that the Antarctic Convergence has encouraged even higher biogenic productivity during the last 500,000 years as the result of enhanced upwelling.

\section{ACKNOWLEDGMENTS}

This research was supported by U.S. National Science Foundation Grants GV-28305 (Office of Polar Programs) and GA-35252 (Geological Oceanography) to J. P. Kennett. We appreciate valuable editorial assistance from Stan M. White, Science Editor at the Deep Sea Drilling Project. 


\section{REFERENCES}

Andrews, J. E., Packham, G., Eade, I. V., Holdsworth, B. K., Jones, D. L., deVries, P., Kleine, G., Kroenke, L. W., Saito, T., Shafik, S., Stoeser, D. G., and van der Lingen, G. J., 1973. Southwest Pacific structures: Geotimes, v. 18, p. 18-21.

Barker, P. F. and Griffiths, D. H., 1972. The evolution of the Scotia Ridge and Scotia Sea: Roy. Soc. London Phil. Trans. Ser. A, v. 271 , p. $151-183$.

Benson, R. H., in press. The origin of the psychrosphere as recorded in changes of deep-sea ostracode assemblage structure: Lethaia.

Berggren, W. A., 1971. Tertiary boundaries and correlations. In Funnell, B. M. and Riedel, W. R. (Eds.) The micropaleontology of oceans: Cambridge (Cambridge University Press), p. 693-809.

Brown, D. A., Campbell, K. S., and Crook, K. A. W., 1968. The geological evolution of Australia and New Zealand: New York (Pergamon Press), p. 409.

Burns, R. E., Andrews, J. E., et al., 1973. Initial Reports of the Deep Sea Drilling Project, Volume 21: Washington (U.S. Government Printing Office).

Callahan, J., 1971. Velocity structure and flux of the Antarctic Circumpolar Current south of Australia: J. Geophys. Res. v. $76(24)$, p. $5859-5870$.

Carter, R. M. and Landis, C. A., 1972. Correlative Oligocene unconformities in southern Australasia: Nature Phys. Sci., v. 237 , p. 12 .

Christoffel, D. and Falconer, R., 1972. Marine magnetic measurements in the southwest Pacific Ocean and the identification of new tectonic features. In Hays, D. (Ed.), Antarctic Oceanology II: The Australian-New Zealand Sector: Antarctic Res. Ser., v. 19, Washington (Am. Geophys. Union). p. 197-209.

Dalziel, I. W. D. and Elliot, D. H., 1971. Evolution of the Scotia Arc: Nature, v. 233 , p. 246-252.

Davies, H. L. and Smith, I. E., 1971. Geology of eastern Papua: Geol. Soc. Am. Bull., v. 82(12), p. 3299-3312.

Devereux, I., 1967. Oxygen isotope paleotemperature measurements of New Zealand Tertiary fossils: New Zealand J. Sci., v. 10, p. 988-1011.

Douglas, R. G., 1973. Evolution and bathymetric distribution of tertiary deep-sea benthic foraminifera: Program Abs. Geol. Soc. Am., p. 603.

Douglas, R. G. and Savin, S. M., 1973. Oxygen and carbon isotope analysis of Cretaceous and Tertiary foraminifera from the central North Pacific. In Winterer, E. L., Ewing, J. L., et al., Initial Reports of the Deep Sea Drilling Project, Volume 17: Washington (U.S. Government Printing Office), p. 591-605.

Echols, R. J., 1973. Foraminifera, Leg 19, Deep Sea Drilling Project. In Creager, J. S., Scholl, D. W., et al., Initial Reports of the Deep Sea Drilling Project, Volume 19: Washington, (U.S. Government Printing Office), p. 721735.

Edwards, A. R., 1973. Southwest Pacific regional unconformities encountered during Leg 21. In Burns, R. E., Andrews, J. E., et al. Initial Reports of the Deep Sea Drilling Project, Volume 21: Washington (U.S. Government Printing Office), p. 641-691.

Elliot, J. L., 1972. Continental drift and basin development in south eastern Australia: Australian Petrol. Expl. Assoc. J., v. 12 , p. $46-51$.

Fofonoff, N. D., 1956. Some properties of sea water influencing the formation of bottom water: Deep-Sea Res., v. 4, p. Washington

Frakes, L. A. and Kemp, E. M., 1973. Paleogene continental positions and evolution of climate. In Tarling, D. H. and
Runcorn, S. K., (Eds.) Implications of Continental Drift to the Earth Sciences, Vol. 1, London and New York (Academic Press), p. 539-559.

Geitzenauer, K. R., Margolis, S. V., and Edwards, D. S., 1968. Evidence consistent with Eocene glaciation in a South Pacific deep-sea sedimentary core: Earth Planet. Sci. Lett., v. 4, p. 173-177.

Gill, A. E. and Bryan, K., 1971. Effects of geometry on the circulation of a three-dimensional southern hemisphere ocean model: Deep-Sea Res., v. 18, p. 685.

Gordon, A. L., 1967. Geostrophic transport through the Drake Passage: Science, v. 156, p. 1732-1734.

1971. Oceanography of Antarctic waters: Antarctic Res. Ser., v. 15, Washington (Am. Geophys. Union), p. 169-204.

1973. Physical oceanography: Antarctic J. U.S., v. 8(3), p. 61-69.

Hayes, D. E. and Ringis, I., 1973. Seafloor spreading in the Tasman Sea: Nature, v. 243(5407), p. 454-458.

Hayes, D. E., Frakes, L. A., Barrett, P., Burns, D. A., Chen, P.-H., Ford, A. S., Kaneps, A. G., Kemp, E. A., McCollum, D. W., Piper, D. J. W., Wall, R. E., and Webb, P. N., 1973. Leg 28 deep-sea drilling in the Southern Ocean: Geotimes, v. 18(6), p. 19-24.

Heath, G. R., 1969. Carbonate sedimentation in the abyssal equatorial Pacific during the past 50 million years: Geol. Soc. Am. Bull., v. 80 , p. 689-694.

Hornibrook, N. de B., 1971. New Zealand Tertiary climate: Paleontological Laboratories Contribution, New Zeland Geological Survey Report 47.

Jenkins, D. G., 1968. Variations in the number of species and subspecies of planktonic Foraminiferaida as an indicator of New Zealand Cenozoic paleotemperatures: J. Paleogeog, Paleoclimatolog, Paleoecology, v. 5, p. 309-313. in press. Paleogene planktonic foraminifera of New Zealand and the austral region: J. Foram. Res.

Johnson, D. A., 1973. Ocean-floor erosion in the equatorial Pacific: Geol. Soc. Am. Bull., v. 83, p. 3121-3144.

Kemp, E. M., 1972. Reworked palynomorphs from the west ice shelf area, East Antarctica, and their possible geological and paleoclimatological significance: Marine Geol. v. 13, p. 145-157.

Kennett, J. P., 1966. Foraminiferal evidence for a shallow calcium carbonate solution boundary, Ross Sea, Antarctica: Science, v. 153(3733), p. 191-193.

, 1967. Recognition and correlation of the Kapitean Stage (upper Miocene) New Zealand: New Zealand J. Geol. Geophys., v. 10(4), p. 1051-1063.

1973. Middle and Late Cenozoic planktonic foraminiferal biostratigraphy of the southwest Pacific-DSDP Leg 21. In Burns, R. E., Andrews, J. E., et al., Initial Reports of the Deep Sea Drilling Project, Volume 21: Washington (U.S. Government Printing Office), p. 575-639.

Kennett, J. P., Burns, R. E., Andrews, J. E., Churkin, M., Davies, T. A., Dumitrica, P., Edwards, A. R., Galehouse, J. S., Packham, G. H., and van der Lingen, G. J., 1972. Australian-Antarctic continental drift, paleocirculation changes and Oligocene deep-sea erosion: Nature Phys.Sci., v. 239(91), p. 51-55.

LeMasurier, W. E., 1972. Volcanic record of Cenozoic glacial history, Marie Byrd Land, Antarctica. In Adie, R. I., (Ed.), Antarctic geology and geophysics: Oslo (Universitetsforlaget), p. 251-259

Lillie, A. R. and Brothers, R. N., 1970. The geology of New Caledonia: New Zealand J. Geol. Geophys., v. 13(1), p. 145-183.

Ludbrook, N. H., 1967. Correlation of Tertiary rocks of the Australasian region: In Tertiary correlations and climatic 
changes in the Pacific: Pacific Sci. Congr., 11th, Tokyo, Symp. 25, p. 7-19.

McGowran, B., 1973. Rifting and drift of Australia and the migration of mammals: Science, v. 180 , p. 759-761.

McTavish, R. A., 1966. Planktonic foraminifera from the Malaita group, British Solomon Islands: Micropaleontology, v. 12(1), p. 1-36.

Margolis, S. V. and Kennett, J. P., 1970. Antarctic glaciation during the Tertiary recorded in sub-Antarctic deep-sea cores: Science. v. 170, p. 1085-1087.

1971. Cenozoic paleoglacial history of Antarctica recorded in subantarctic deep-sea cores: Am. J. Sci., v. 271, p. 1-36.

Mercer, J. H., 1972. Cainozoic temperature trends in the Southern Hemisphere: Antarctic and Andean glacial evidence. In Paleoecology of Africa: v. 8, p. 85-114.

Moberly, R., 1972. Origin of lithosphere behind island arcs, with reference to the Western Pacific: Geol. Soc. Am. Mem. 132, p. 35-55.

Moore, T. C., 1972. DSDP: Successes, failures, proposals: Geotimes, v. 17(7), p. 29-31.

Mosby, H., 1971. South Atlantic bottom water: Symposium on Antarctic ice and water masses: Sci. Comm., Antarctic Res., Tokyo, 1970, p. 11-20.

Pimm, A. C. and Hayes, D. E., 1972. General Synthesis. In Hayes, D. E., Pimm, A. C., et al., Initial Reports of the Deep Sea Drilling Project, Volume 14: Washington (U.S. Government Printing Office), p. 955-975.

Raven, P. H. and Axelrod, D. I., 1972. Plate tectonics and Australasian paleobiogeography: Science, v. 176, p. 13791386.

Reid, J. L. and Nowlin, W. D., 1971. Transport of water through the Drake Passage: Deep-Sea Res., v. 18, p. 51-64.

Rickwood, F. K., 1968. The geology of western Papua: Australian Petrol. Expl. Assoc. J., v. 8, p. 51-61.

Rodda, P., 1967. Outline of the geology of Vita Levu: New Zealand J. Geol. Geophys. v. 10, p. 1260-1273.
Rona, P. A., 1973. Worldwide unconformities in marine sediments related to eustatic changes of sea level: Nature Phys. Sci. v. 244, p. 25-26.

Schnitker, D., 1974. West Atlantic abyssal circulation during the past 120,000 years: Nature, v. 248, p. 385-387.

Streeter, S. S., 1973. Bottom water and benthonic foraminifera in the North Atlantic-glacial-interglacial contrasts: J. Quatern. Res., v. 3(1), p. 131-141.

Thompson, J. E., 1967. A geological history of eastern New Guinea: Australian Petrol. Expl. Assoc. J., v. 7, p. 83-93.

Van Andel, T. H. and Moore, T. C., Jr., 1974. Cenozoic calcium carbonate distribution and calcite compensation depth in the central equatorial Pacific Ocean: Geology, v. 2(2), p. 87-92.

Warren, B. A., 1973. Transpacific hydrographic sections at lat. $43^{\circ} \mathrm{S}$ and $28^{\circ} \mathrm{S}$ : The SCORPIO Expedition-II Deep Water: Deep-Sea Res., v. 20, p. 9-38.

Warren, B. A. and Voorhis, A. D., 1970. Velocity measurements in the deep western boundary current of the South Pacific: Nature, v. 228, p. 849-850.

Watkins, N. D. and Kennett, J. P., 1972. Regional sedimentary disconformities and upper Cenozoic changes in bottom water velocities between Australasia and Antarctica: Antarctic Res. Ser., Washington (Am. Geophys. Union), v. 19 , p. 273-293.

Weissel, J. K., and Hayes, D. E., 1972. Magnetic anomalies in the Southeast Indian Ocean: Antarctic Res. Ser. v. 19, Washington (Am. Geophys. Union), v. 19, p. 165-196.

Weyl, P. K., 1968. The role of the oceans in climatic change: a theory of the ice ages: Meteorol. Monogr., v. 8(30), p. 3762.

Wolfe, J. A. and Hopkins, D. M., 1967. Climatic changes recorded by Tertiary land floras in northwestern North America. In Tertiary correlations and climatic changes in the Pacific: Pacific Sci. Congr., 11th, Tokyo, p. 67-76. 